\title{
Influence of Heavy Metals on Seed Germination and Early Seedling Growth in Eruca sativa Mill.
}

\author{
Yuan Zhi' ${ }^{1}$, Zhaohui Deng' ${ }^{2}$ Mingdan Luo', Wei Ding1, Yaqin Hu', Jianfang Deng1, Yanyan Li', \\ Yanping Zhao', Xuekun Zhang' ${ }^{3}$, Wenhua $\mathrm{Wu}^{1 *}$, Bangquan Huang1 \\ ${ }^{1}$ Hubei Collaborative Innovation Center for Green Transformation of Bio-Resources, College of Life Science, \\ Hubei University, Wuhan, China \\ ${ }^{2}$ Vocational and Technical College of Anshun, Anshun, China \\ ${ }^{3}$ Oil Crops Research Institute of CAAS, Key Laboratory Biology and Genetic Improvement of Oil Crops, Ministry \\ of Agriculture, Wuhan, China \\ Email: ${ }^{*}$ 1305142468@qq.com
}

Received 31 December 2014; accepted 8 March 2015; published 11 March 2015

Copyright $@ 2015$ by authors and Scientific Research Publishing Inc.

This work is licensed under the Creative Commons Attribution International License (CC BY). http://creativecommons.org/licenses/by/4.0/

c) (i) Open Access

\begin{abstract}
Heavy metals present in soil and water naturally or as contaminants from human activities can cause bioaccumulation affecting the entire ecosystem and pose harmful health consequences in all life forms. Some famous non-food hyperaccumulators such as Thlaspi caerulescens, Sedum alfredii, Pteris vittata, Arabidopsis halleri and Athyrium yokoscense are of very little economic value, making it difficult for them to be used for phytoremediation. In this paper, the influence of heavy metals $\mathrm{Cu}, \mathrm{Ni}, \mathrm{Zn}, \mathrm{Hg}, \mathrm{Cr}, \mathrm{Pb}$ and $\mathrm{Cd}$ on seed germination and early seedling growth in oil crop Eruca sativa was evaluated under laboratory conditions. Our results indicated that among the 7 heavy metals tested, only $\mathrm{Ni}$ at higher concentrations ( $1 \mathrm{mM}$ and above) significantly decreased the Eruca seed germination in a dose-dependent manner. All heavy metals except $\mathrm{Zn}$ and $\mathrm{Ni}$ decreased the root length first, then the shoot length or the fresh seedling weight, and seed germination was always the last to be influenced. With $\mathrm{Ni}$, the root length, shoot length and fresh seedling weight were stimulated when $\mathrm{Ni}$ concentrations were under $1 \mathrm{mM}$; with $\mathrm{Zn}$, the root length, shoot length and fresh seedling weight were increased by all concentrations tested $(0.20-5.0 \mathrm{mM})$. Our results indicated that Eruca is tolerant or moderately tolerant to $\mathrm{Cu}, \mathrm{Hg}, \mathrm{Cr}$, and $\mathrm{Cd}$ and highly tolerant to $\mathrm{Pb}, \mathrm{Ni}$ and $\mathrm{Zn}$, and can be developed as an industrial oil crop for phytoremediation of soils contaminated by heavy metals.
\end{abstract}

\footnotetext{
${ }^{*}$ Corresponding author.
} 


\section{Keywords}

\section{Eruca sativa, Heavy Metal, Phytoremediation, Seed Germination, Early Seedling Growth}

\section{Introduction}

Heavy metals such as $\mathrm{Cu}, \mathrm{Zn}, \mathrm{Ni}, \mathrm{Hg}, \mathrm{Cd}, \mathrm{Cr}$ and $\mathrm{Pb}$ present in soil and water naturally or as contaminants from human activities can cause bioaccumulation affecting the entire ecosystem and pose harmful health consequences in all life forms [1]. Application of phytoextraction can reduce phyto-available metals in the soil and thereby diminish toxic metal contents in agricultural products. Some famous hyperaccumulators have been deeply researched such as Cd/Zn hyperaccumulator Thlaspi caerulescens [2] [3], Sedum alfredii [4] [5], As hyperaccumulator Pteris vittata [6] [7], Cd hyperaccumulator Solanum nigrum [8], Arabidopsis halleri [9], Athyrium yokoscense and a number of ferns belonging to the genus Pteris [10]. However, these hyperaccumulators are of very little economic value, making it difficult for them to be used in phytoremediation.

Eruca sativa Mill. in Brassicaceae family is an important marginal crop grown on soil with reduced fertility and is preferred over other relative species for its tolerance and adaptability to unfavorable environmental conditions [11]-[15]. Eruca lines with larger and yellow seeds, higher plant and seed yield were available [16]. Its seed oil is used for human nutrition, medicinal and cosmetic properties, and as a lubricant [14] [17]. By using its regeneration [18] and genetic transformation system [19] available, Eruca can be developed into a safe industrial oil crop, because of its low cross ability with the edible oilseed rape [20] and its resistance to powdery mildew [12], stem rot [21] and salt [22]. The present study was made to determine the influence of heavy metals $\mathrm{Cu}, \mathrm{Ni}$, $\mathrm{Zn}, \mathrm{Pb}, \mathrm{Cd}, \mathrm{Cr}$ and $\mathrm{Hg}$ on Eruca seed germination, early seedling growth and the potential of using Eruca for phytoremediation of soils contaminated by heavy metals.

\section{Materials and Methods}

Healthy seeds of Eruca sativa cv. hubu-14 from Hubei University were inoculated on sand cultures with different concentrations of heavy metals. The heavy metals except $\mathrm{Pb}$ were dissolved in liquid MS without sugar and organic components. $\mathrm{Pb}$ was dissolved in $\mathrm{ddH}_{2} \mathrm{O}$ to avoid precipitation. Different concentrations of heavy metals were prepared from $\mathrm{CuSO}_{4} \cdot 5 \mathrm{H}_{2} \mathrm{O}, \mathrm{ZnSO}_{4} \cdot 7 \mathrm{H}_{2} \mathrm{O}, \mathrm{NiSO}_{4} \cdot 6 \mathrm{H}_{2} \mathrm{O}, \mathrm{K}_{2} \mathrm{Cr}_{2} \mathrm{O}_{7}, \mathrm{~Pb}\left(\mathrm{NO}_{3}\right)_{2}, \mathrm{HgCl}_{2}$ and $\mathrm{CdCl}_{2} \cdot 2 \frac{1}{2} \mathrm{H}_{2} \mathrm{O}$. Seed germination rates were scored 4 days after inoculation and root length, shoot length and fresh seedling weight were measured 7 - 8 days after seed inoculation. The relative seed germination, root length, shoot length and fresh seedling weight were calculated as that of treatments with heavy metals divided by that of controls. The incubation temperature was set at $25^{\circ} \mathrm{C}$ with a 16-hr photo period under $2000 \mathrm{~lx}$. The experiment was arranged in a completely randomized design with three replicates, each replicate with about 50 Eruca seeds. Variance analyses and multiple comparisons were carried out on SPSS 19.0.

\section{Results and Discussion}

Variance analyses indicated that among the 7 heavy metals tested only $\mathrm{Ni}(1 \mathrm{mM}$ and above) decreased significantly $(\mathrm{P}<0.05)$ the Eruca seed germination in a dose-dependent manner (Figure 1), suggesting that Eruca seed germination was pretty tolerant to heavy metals. All heavy metals except $\mathrm{Zn}$ and Ni decreased the root length first, then shoot length or fresh seedling weight, and finally seed germination. With Ni the root length, shoot length and fresh seedling weight were stimulated when Ni concentrations were under $1 \mathrm{mM}$; with $\mathrm{Zn}$ the Eruca root length, shoot length and fresh seedling weight were increased by 0.2 - $5.0 \mathrm{mM} \mathrm{Zn} \mathrm{(Figures} \mathrm{2-4).}$

\subsection{The Influence of $\mathrm{Cu}$}

In maize, the seed germination was increased by $3.98 \%$ at $0.1 \mathrm{mM} \mathrm{Cu}$ [23]. However, most studies indicated that $\mathrm{Cu}$ significantly decreased the seed germination. With $10 \mu \mathrm{M} \mathrm{Cu}$ treatment, wheat and rice seed germination was reduced by more than $35 \%$ and $60 \%$, respectively [24]. In alfalfa, $40 \mathrm{mg} \cdot \mathrm{L}^{-1} \mathrm{Cu}$ inhibited significantly seed germination by $39.0 \%$ [25]. In Crambe, higher $\mathrm{Cu}$ concentration $\left(0.7 \mathrm{mM}\right.$ or $44.8 \mathrm{mg} \cdot \mathrm{L}^{-1}$ and above) decreased Crambe seed germination significantly [26]. In our experiment, all $\mathrm{Cu}$ concentrations tested (0.3 - 1.2 


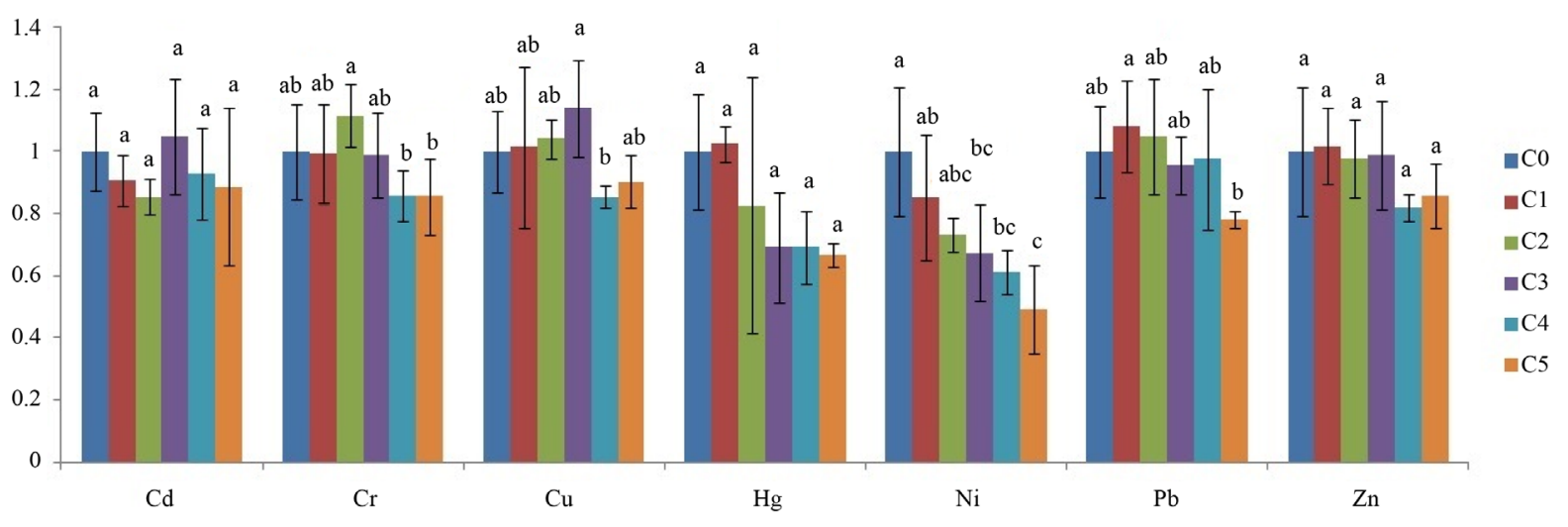

Figure 1. Influence of heavy metals on relative seed germination in Eruca. Note: Cd: C0 = 0, C1 $=0.10 \mathrm{mM}, \mathrm{C} 2=0.20$ $\mathrm{mM}, \mathrm{C} 3=0.30 \mathrm{mM}$, C4 $=0.38 \mathrm{mM}, \mathrm{C} 5=0.46 \mathrm{mM}$; Cr: C1 $=0.05 \mathrm{mM}, \mathrm{C} 2=0.10 \mathrm{mM}, \mathrm{C} 3=0.20 \mathrm{mM}, \mathrm{C} 4=0.40 \mathrm{mM}$, $\mathrm{C} 5=0.80 \mathrm{mM}$; Cu: C1 = $0.30 \mathrm{mM}, \mathrm{C} 2=0.50 \mathrm{mM}, \mathrm{C} 3=0.70 \mathrm{mM}, \mathrm{C} 4=0.90 \mathrm{mM}, \mathrm{C} 5=1.20 \mathrm{mM} ; \mathrm{Hg}: \mathrm{C} 1=0.10 \mathrm{mM}, \mathrm{C} 2=$ $0.20 \mathrm{mM}, \mathrm{C} 3=0.30 \mathrm{mM}, \mathrm{C} 4=0.40 \mathrm{mM}, \mathrm{C} 5=0.50 \mathrm{mM}$; Ni: C1 $=0.20 \mathrm{mM}, \mathrm{C} 2=0.40 \mathrm{mM}, \mathrm{C} 3=1.00 \mathrm{mM}, \mathrm{C} 4=3.00 \mathrm{mM}$, $\mathrm{C} 5=5.00 \mathrm{mM}$; Pb: C1 = $0.80 \mathrm{mM}, \mathrm{C} 2=3.20 \mathrm{mM}, \mathrm{C} 3=4.00 \mathrm{mM}, \mathrm{C} 4=5.00 \mathrm{mM}, \mathrm{C} 5=5.50 \mathrm{mM} ; \mathrm{Zn}: \mathrm{C} 1=0.20 \mathrm{mM}, \mathrm{C} 2=$ $0.40 \mathrm{mM}, \mathrm{C} 3=1.00 \mathrm{mM}, \mathrm{C} 4=3.00 \mathrm{mM}, \mathrm{C} 5=5.00 \mathrm{mM}$.

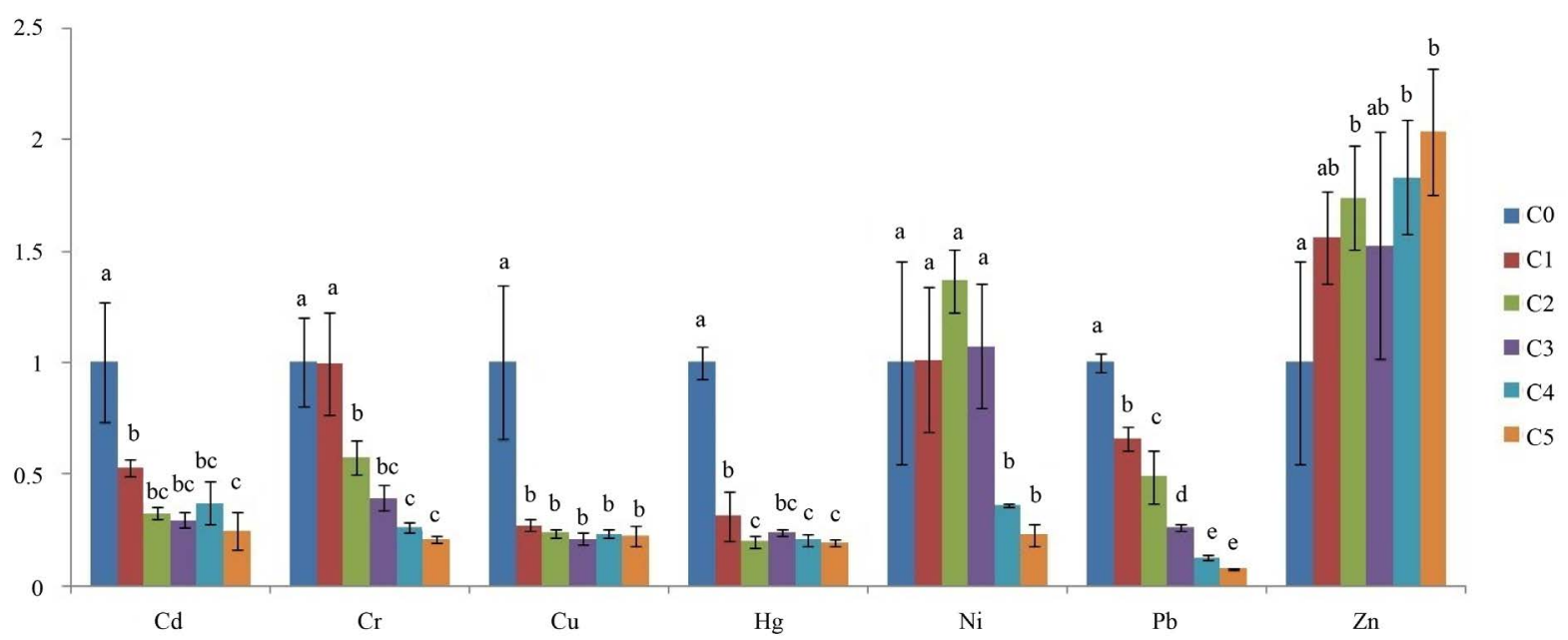

Figure 2. Influence of heavy metals on relative root length in Eruca. Note: the heavy metal concentrations are the same as in Figure 1.

$\mathrm{mM}$ ) did not decrease the Eruca seed germination significantly $(\mathrm{P}>0.05)$. Lower Cu concentration $(<0.7 \mathrm{mM})$ even increased the seed germination (Figure 1), suggesting that Eruca seed germination is quite tolerant to Cu. In alfalfa $\mathrm{Cu}$ caused a shoot elongation reduction of $69.0 \%$ at the dose of $40 \mathrm{ppm}$ [25]. Taylor and Foy [27] found $30 \mu \mathrm{M} \mathrm{Cu}$ enough for reducing growth of wheat by 50\%, whereas Wheeler et al. [28] reported that only $0.5 \mu \mathrm{M} \mathrm{Cu}$ was required for a 50\% growth reduction in the same species. In Arabidopsis, $0.2 \mathrm{mM} \mathrm{Cu}$ inhibited the seedling growth by about 60\% [29]. In Crambe, $0.3 \mathrm{mM} \mathrm{Cu}$ decreased root length by 75.33\%, shoot length by $29.44 \%$ and fresh seedling weight by $22.26 \%$ [26]. In our experiment, $0.3 \mathrm{mM} \mathrm{Cu}\left(19.2 \mathrm{mg} \cdot \mathrm{L}^{-1}\right)$ decreased Eruca root length by $72.67 \%$, shoot length by $24.67 \%$ and fresh seedling weight by $24 \%$ (Figures $2-4$ ). This also indicated that Eruca is moderately tolerant to Cu regarding early seedling growth.

\subsection{The Influence of $\mathrm{Zn}$}

In alfalfa a concentration of $40 \mathrm{mg} \cdot \mathrm{L}^{-1} \mathrm{Zn}$ did not significantly reduce the seed germination [25]. In wheat and rice the seed germination was not significantly affected by Zn concentration [24], but in another study on wheat, the germination was completely inhibited at $10 \mathrm{mg} \cdot \mathrm{L}^{-1} \mathrm{Zn}$ [30]. In Crambe $0.85 \mathrm{mM}\left(55.25 \mathrm{mg} \cdot \mathrm{L}^{-1}\right) \mathrm{Zn} \mathrm{did} \mathrm{not}$ significantly decrease Crambe seed germination [26]. Our results indicated that all Zn concentrations tested (0.2 - 


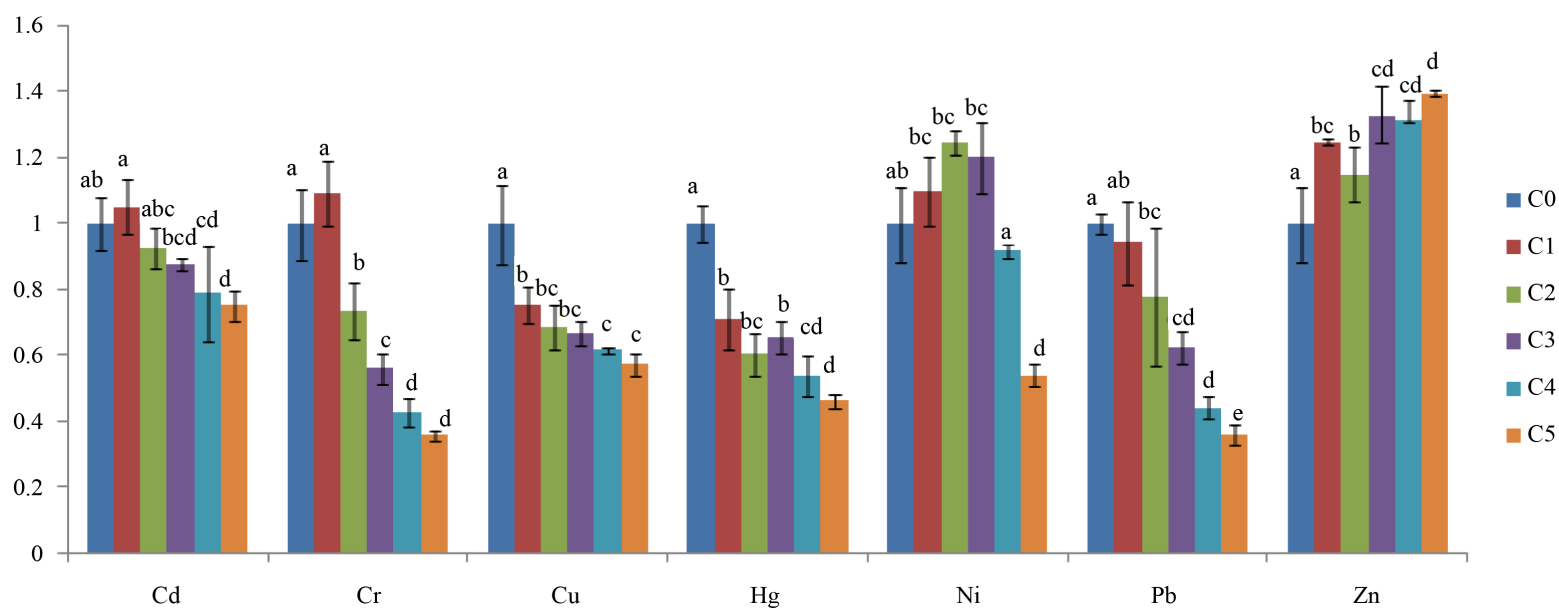

Figure 3. Influence of heavy metals on relative shoot length in Eruca. Note: the heavy metal concentrations are the same as in Figure 1.

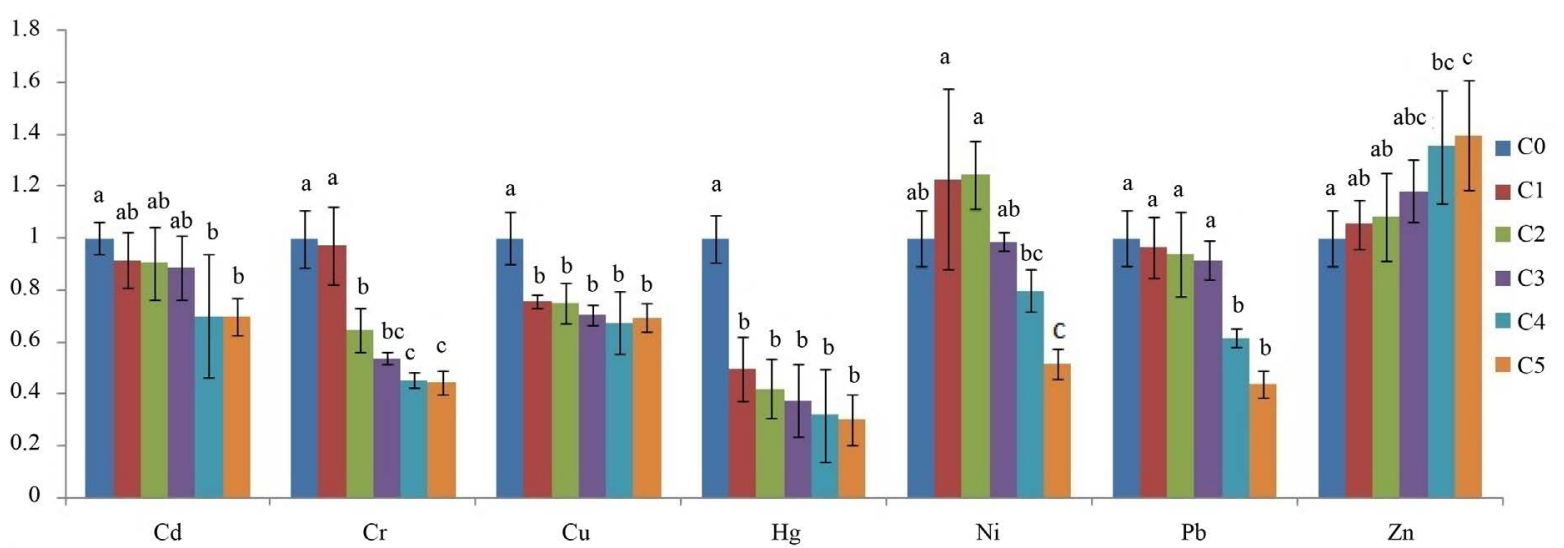

Figure 4. Influence of heavy metals on relative fresh seedling weight in Eruca. Note: the heavy metal concentrations are the same as in Figure 1.

$5.0 \mathrm{mM}$ ) did not significantly decrease Eruca seed germination (Figure 1), suggesting that Eruca seed germination is very tolerant to $\mathrm{Zn}$. In alfalfa all $\mathrm{Zn}$ concentrations increased the root length by more than $100.0 \%$, and 40 ppm of Zn increased the shoot growth by $10 \%$ over control [25]. In Sedum alfredii the specific root length in non-hyperaccumulating ecotype was significantly reduced by $47.2 \%$, while the SRL of hyperaccumulating ecotype was significantly increased under the treatment of $500 \mu \mathrm{M} \mathrm{Zn} \mathrm{[31].} \mathrm{In} \mathrm{another} \mathrm{study} \mathrm{on} \mathrm{S.} \mathrm{alfredii,} \mathrm{it} \mathrm{was}$ noted that root length, surface-area and volume of the hyperaccumulating ecotype increased obviously under $1224 \mu \mathrm{M}$ Zn treatment, whereas in non-hyperaccumulating ecotype these parameter were decreased significantly [5]. In Arabidopsis thaliana the root length was decreased by about 55\% while the shoot length was decreased by about $50 \%$ at $1 \mathrm{mM} \mathrm{Zn} \mathrm{[32].} \mathrm{In} \mathrm{another} \mathrm{study} \mathrm{on} \mathrm{Arabidopsis} \mathrm{thaliana,} \mathrm{the} \mathrm{Zn}$ concentration required for a $50 \%$ inhibition of root growth was $98 \mu \mathrm{M}$ [33]. In Crambe, Zn inhibited root length by about 76.33\%, shoot length by $43.48 \%$ and fresh seedling weight by $47.84 \%$ at $0.1 \mathrm{mM}$ concentration [26]. In the hyperaccumulator species Thlaspi goesingense, the $\mathrm{Zn}$ concentration required for a 50\% inhibition of root growth was higher than $500 \mu \mathrm{M}$. In a study on Eruca the root length was decreased by $31.54 \%$ and shoot length by $28.89 \%$ at $50 \mathrm{mg} \cdot \mathrm{L}^{-1}$ [34]. Ozdener and Aydin [35] found that the Eruca root length increased significantly by $54.79 \%$ and fresh root weight by $88.89 \%$ when $500 \mu \mathrm{g} \cdot \mathrm{g}^{-1} \mathrm{Zn}$ was applied. In our experiment, the root length, shoot length and fresh seedling weight were increased by all Zn concentrations tested $(0.20-5.0 \mathrm{mM})$. When the Zn concentration was increased to $5 \mathrm{mM}$, the root length was almost doubled, the shoot length was increased by $39.67 \%$ and fresh seedling weight was increased by $40 \%$ (Figures 2-4), suggesting that Eruca is highly tolerant to Zn regarding 
early seedling growth.

\subsection{The Influence of $\mathrm{Ni}$}

In alfalfa $40 \mathrm{ppm} \mathrm{Ni}$ inhibited significantly seed germination by $24.0 \%$ [25]. In maize Ni decreased the seed germination by $10.84 \%$ at $10 \mu \mathrm{M}$ [23]. In another study on maize, at $50 \mathrm{mg} \cdot \mathrm{L}^{-1} \mathrm{Ni}$ the seed germination was decreased by $11.70 \%$ [36]. In Salicornia brachiata the seed germination was decreased by $49.36 \%$ at $50 \mu \mathrm{M} \mathrm{Ni}$ [18]. In Crambe the root growth was completely inhibited at over $80 \mu \mathrm{M} \mathrm{Ni}$ [26]. In our experiment the Eruca seed germination was only significantly influenced by higher Ni concentrations (1 mM and above, Figure 1$)$. Ni at $1 \mathrm{mM}$ only decreased the seed germination by $32.67 \%$, suggesting that Eruca seed germination is tolerant to Ni. In maize, $10 \mu \mathrm{M}$ Ni decreased the root length by $19.44 \%$ and shoot length by $39.13 \%$ [36]. In hyperaccumulator species Thlaspi goesingense, Ni concentration required for 50\% inhibition of root growth was higher than $500 \mu \mathrm{M}$ [33]. In Arabidopsis thaliana, Ni concentration required for 50\% inhibition of root growth was $80 \mu \mathrm{M}$ [33]. Schaaf et al. [37] found that fresh weight of Arabidopsis thaliana was almost not affected by $50 \mu \mathrm{M} \mathrm{Ni}$. In Crambe only $0.4 \mu \mathrm{M}$ Ni significantly decreased root length by $5.33 \%$ and $1.2 \mu \mathrm{M} \mathrm{Ni}$ decreased root length by $71 \%$, shoot length by $60 \%$ and fresh seedling weight by $73.42 \%$ [26]. In our experiment $0.4 \mathrm{mM}$ Ni significantly increased the root length by $35 \%$, shoot length by $24.67 \%$, and fresh seedling weight also by $24.67 \%$; only 3.0 $\mathrm{mM} \mathrm{Ni}$ significantly decreased the root length by $63.67 \%$, shoot length by $8.33 \%$, and fresh seedling weight by 20.33\% (Figures 2-4), suggesting that Eruca is highly tolerant to Ni regarding early seedling growth.

\subsection{The Influence of $\mathrm{Cd}$}

In alfalfa the concentration of $40 \mathrm{ppm} C d$ inhibited significantly seed germination by $44.0 \%$ [25]. In wheat, the seed germination was decreased by $60 \%$ at $10 \mathrm{mg} \cdot \mathrm{L}^{-1} \mathrm{Cd}$ [30]. In Sinapis arvensis, $1000 \mu \mathrm{M}$ Cd significantly decreased the seed germination by 5.6\% [38]. In Crambe, seed germination was not significantly affected by all Cd concentrations (0.10 - $0.46 \mathrm{mM})$ tested [26]. In our experiment the Eruca seed germination was not significantly affected by all the Cd concentrations $(0.10-0.46 \mathrm{mM})$ tested in this study (Figure 1), suggesting that Eruca seed germination is tolerant to $\mathrm{Cd}$. In castor bean $1 \mathrm{mg} \cdot \mathrm{L}^{-1}$ of Cd caused a reduction of $44 \%$ in the root dry mass and 53\% in the shoot dry mass [39]. In Sinapis arvensis, the root length was decreased significantly by $92.62 \%$, shoot length by $56.31 \%$ and fresh seedling weight by $49.69 \%$ at $150 \mu \mathrm{M} \mathrm{Cd}$ [38]. In Brassica juncea, the root length was decreased by about $37.5 \%$ at $0.20 \mathrm{mM}$ Cd and fresh seedling weight by $70 \%$ at $0.05 \mathrm{mM} \mathrm{Cd}$ and more than $90 \%$ by $0.075 \mathrm{mM} \mathrm{Cd} \mathrm{[40].} \mathrm{In} \mathrm{Arabidopsis} \mathrm{halleri,} 5 \mu \mathrm{M} \mathrm{Cd}$ decreased shoot growth by $45 \%$, whereas $5-50 \mu \mathrm{M} \mathrm{Cd}$ had no significant effect on root biomass. At $100 \mu \mathrm{M} \mathrm{Cd}$ shoot and root growth were inhibited by $82 \%$ and $74 \%$, respectively [41]. In Arabidopsis thaliana, the Cd concentration required for $50 \%$ inhibition of root growth was only $38 \mu \mathrm{M}$ [33]. In Crambe, $0.1 \mathrm{mM} \mathrm{Cd}\left(11.2 \mathrm{mg} \cdot \mathrm{L}^{-1}\right)$ decreased Crambe root length by $47.67 \%$, shoot length by $33.67 \%$, fresh seedling weight by $13 \%$ [26]. Plant height was significantly decreased at 50 and $100 \mathrm{ppm}$ Cd in Raphanus sativus and in Eruca sativa at $50 \mathrm{ppm}$ Cd only by $40.6 \%, 31.1 \%$, and $14.7 \%$ respectively [42]. Fresh weight was significantly increased at 100 and $200 \mathrm{ppm}$ Cd in Raphanus sativus by $17.2 \%$, 27.6\%, respectively. In Eruca sativa, fresh weight was significantly increased by addition of Cd at $200 \mathrm{ppm}$ by 53.8\%. Dry weight increased in Raphanus sativus at 50 - $200 \mathrm{ppm}$ Cd [42]. In another study on Eruca, the root length was decreased by $27.69 \%$, shoot length by $43.78 \%$ at $50 \mathrm{mg} \cdot \mathrm{L}^{-1} \mathrm{Cd}$ [34]. In our experiment the root length was decreased by $47.33 \%$ at $0.10 \mathrm{mM} \mathrm{Cd}$, while the shoot length and fresh seedling weight were not significantly influenced by $0.10 \mathrm{mM}$ Cd (Figures 2-4), suggesting that Eruca is tolerant to Cd.

\subsection{The Influence of $\mathrm{Hg}$}

In Festuca arundinacea, the seed germination was decreased by $4.00 \%$ at $50 \mathrm{mg} \cdot \mathrm{L}^{-1} \mathrm{Hg}$ [43]. In cucumber, the root and shoot growth was almost completely inhibited at $250 \mu \mathrm{M} \mathrm{HgCl}_{2}$ [44]. In Brassica juncea, treatment with $2 \mu \mathrm{M} \mathrm{Hg}$ for $24 \mathrm{~h}$ inhibited the root growth by about 80\% [45]. Also in Brassica juncea, treatment at 16.7 $\mathrm{mg} \cdot \mathrm{L}^{-1} \mathrm{Hg}$ for two weeks decreased the dry weight of root and shoot by more than $60 \%$ [46]. In Brassica napus, the biomass was decreased by about $60 \%$ at $10 \mathrm{mg} \cdot \mathrm{L}^{-1} \mathrm{Hg}$ [47]. In Crambe, $\mathrm{Hg}$ significantly decreased Crambe seed germination at $0.3 \mathrm{mM}\left(60.3 \mathrm{mg} \cdot \mathrm{L}^{-1}\right)$ by $34.66 \%$. The root length was decreased by $81.33 \%$, shoot length by $46.34 \%$ and fresh seedling weight by $16.94 \%$ at $0.1 \mathrm{mM} \mathrm{Hg}$ [26]. In our experiment the Eruca seed germination was not significantly decreased by all the $\mathrm{Hg}$ concentrations tested $(0.10-0.50 \mathrm{mM}$, Figure 1). $0.1 \mathrm{mM} \mathrm{Hg}$ 
significantly decreased the root length by $68.33 \%$, shoot length by $28.67 \%$ and fresh seedling weight by $50.33 \%$ (Figures 2-4), suggesting that Eruca is only moderately tolerant to Hg.

\subsection{The Influence of $\mathrm{Cr}$}

In alfalfa, the concentration of $40 \mathrm{ppm} \mathrm{Cr}$ inhibited significantly seed germination by 54.0\% [25]. In wheat the germination was decreased by about $30 \%$ at $500 \mathrm{ppm} \mathrm{Cr}$ [48]. In another study on wheat, seed germination was decreased by $80 \%$ at $10 \mathrm{mg} \cdot \mathrm{L}^{-1} \mathrm{Cr}$ [30]. In Crambe, seed germination was not significantly decreased by $\mathrm{Cr}$ concentrations tested $\left(0.05-0.80 \mathrm{mM}\right.$ or $\left.2.6-41.6 \mathrm{mg} \cdot \mathrm{L}^{-1}\right)$ [26]. In our experiment the Eruca seed germination was not significantly decreased by the Cr concentrations tested $(0.05-0.80 \mathrm{mM}$, Figure 1$)$, suggesting that Eruca germination is quite tolerant to $\mathrm{Cr}$. In alfalfa $\mathrm{Cr}$ at $10 \mathrm{ppm}$ increased root growth by approximately $36.0 \%$ [25]. In soybean at 400 and $500 \mathrm{ppm} \mathrm{Cr}$ concentration there was about $83 \%$ and $85 \%$ reduction in length of seedling respectively [48]. With Crambe the fresh weight of plants decreased moderately at $100 \mu \mathrm{M} \mathrm{K}_{2} \mathrm{CrO}_{4}$, whereas at $150 \mu \mathrm{M} \mathrm{K}_{2} \mathrm{CrO}_{4}$ there was a significant reduction in biomass with no symptoms of severe cellular damage, but at higher concentration $(200$ and $250 \mu \mathrm{M})$, plant showed chlorosis and visible necrosis on leaves [49]. Also in Crambe, root length was decreased by $41.33 \%$, shoot length by $15.66 \%$ and fresh seedling weight by $27.67 \%$ at $0.05 \mathrm{mM} \mathrm{Cr}$ [26]. In our experiment $0.10 \mathrm{mM} \mathrm{Cr}$ significantly decreased the root length by 42.33\%, shoot length by $26.33 \%$ and fresh seedling weight by $35.33 \%$ (Figures 2-4), suggesting that Eruca is moderately tolerant to $\mathrm{Cr}$ regarding early seedling growth.

\subsection{The Influence of $\mathrm{Pb}$}

In maize, a significant increase of germination rate was observed for seeds treated with $10 \mu \mathrm{M} \mathrm{Pb}$, while a significant decrease of germination by $12.48 \%$ was determined at $5 \mathrm{mM} \mathrm{Pb}$ [23]. In Sinapis arvensis, the seed germination was decreased significantly by $6.17 \%$ at $1200 \mu \mathrm{M} \mathrm{Pb}$ [38]. In Crambe, seed germination was not significantly decreased by $5.5 \mathrm{mM} \mathrm{Pb}$ [26]. In our experiment Eruca seed germination was not significantly influenced by the $\mathrm{Pb}$ concentrations tested (0.8 - 5.5 mM, Figure 1), suggesting that Eruca seed germination is very tolerant to $\mathrm{Pb}$. Castor bean demonstrated to be tolerant to $0-96 \mathrm{mg} \cdot \mathrm{L}^{-1} \mathrm{~Pb}$ concentrations [39]. In Sinapis arvensis, the root length was decreased significantly by $66.46 \%$, shoot length by $38.62 \%$ and fresh seedling weight by $33.33 \%$ at $300 \mu \mathrm{M} \mathrm{Pb}$ [38]. In Crambe, root growth was decreased by $48.67 \%$, shoot length by $16.33 \%$, and fresh seedling weight by $16.33 \%$ at $0.8 \mathrm{mM} \mathrm{Pb}$ [26]. Fresh weight was significantly increased at 50 and 100 ppm $\mathrm{Pb}$ in Raphanus sativus by $31.0 \%$ and $10.3 \%$ respectively. In Eruca sativa, fresh weight was significantly increased by addition of $\mathrm{Pb}$ at $200 \mathrm{ppm}$ by $61.5 \%$ in comparison with the control. Dry weight increased in $R a-$ phanus sativus and Eruca sativa at $50-200 \mathrm{ppm} \mathrm{Pb} \mathrm{[42].} \mathrm{With} \mathrm{Pb}$ treatment, Eruca root length was decreased by $20.0 \%$, the shoot length by $23.78 \%$ at $50 \mathrm{mg} \cdot \mathrm{L}^{-1}$ [34]. In our experiment $0.8 \mathrm{mM} \mathrm{Pb}$ only decreased root length by $33.67 \%, 3.2 \mathrm{mM}$ only decreased shoot length by $22.67 \%$ and $5 \mathrm{mM} \mathrm{Pb}$ decreased Eruca fresh seedling weight only by $38.67 \%$, while $4 \mathrm{mM} \mathrm{Pb}$ did not significantly decrease the fresh seedling weight (Figures 2-4), suggesting that Eruca is highly tolerant to $\mathrm{Pb}$.

\section{Conclusion}

Our results indicated that Eruca is tolerant or moderately tolerant to $\mathrm{Cu}, \mathrm{Hg}, \mathrm{Cr}, \mathrm{Cd}$ and highly tolerant to $\mathrm{Zn}, \mathrm{Ni}$ and $\mathrm{Pb}$, and can be developed as an industrial oil crop for phytoremediation of soils contaminated by heavy metals. The heavy metal of tolerant Eruca can also be used for cloning genes responsible for heavy metal tolerances.

\section{Acknowledgements}

This work was supported by funds from Science and Technology Department of Hubei Province; Key Laboratory Biology and Genetic Improvement of Oil Crops, Ministry of Agriculture, China; National Natural Science Foundation of China (30771382, 30671334, 30971807, 31201238); an European Committee 7th Framework Programme (ICON, 211400) and Swedish Research Links project.

\section{References}

[1] Munzuroglu, O. and Geckil, H. (2002) Effects of Metals on Seed Germination, Root Elongation, and Coleoptile and Hypocotyls Growth in Triticum aestivum and Cucumis sativus. Archives of Environment Contamination and Toxicolo- 
gy, 43, 203-213. http://dx.doi.org/10.1007/s00244-002-1116-4

[2] Baker, A.J.M., McGrath, S.P., Reeves, R.D. and Smith, J.A.C. (2000) Metal Hyperaccumulator Plants: A Review of the Ecology and Physiology of a Biochemical Resource for Phytoremediation of Metal-Polluted Soils. In: Terry, N. and Bauelos, G., Eds., Phytoremediation of Contaminated Soil and Water, Lewis Publishers, Florida, 85-107.

[3] Liu, G.Y., Zhang, Y.X. and Chai, T.Y. (2011) Phytochelatin Synthase of Thlaspi caerulescens Enhanced Tolerance and Accumulation of Heavy Metals When Expressed in Yeast and Tobacco. Plant Cell Reports, 30, 1067-1076. http://dx.doi.org/10.1007/s00299-011-1013-2

[4] Yang, X.E., Long, X.X., Ye, H.B., He, Z.L., Stoffella, P.J. and Calvert, D.V. (2004) Cadmium Tolerance and Hyperaccumulation in a New Zn-Hyperaccumulating Plant Species (Sedum alfredii Hance). Plant and Soil, 259, 181-189. http://dx.doi.org/10.1023/B:PLSO.0000020956.24027.f2

[5] Li, T.Q., Yang, X.E., Jin, X.F., He, Z.L., Stoffella, P.J. and Hu, Q.H. (2005) Root Responses and Metal Accumulation in Two Contrasting Ecotypes of Sedum alfredii Hance under Lead and Zinc Toxic Stress. Journal of Environment Science and Health, Part A, 40, 1081-1096. http://dx.doi.org/10.1081/ESE-200056163

[6] Ma, L.Q., Komar, K.M., Tu, C., Zhang, W.H., Cai, Y. and Kennelley, E.D. (2001) A Fern That Hyperaccumulates Arsenic: A Hardy, Versatile, Fast-Growing Plant Helps to Remove Arsenic from Contaminated Soils. Nature, 409, 579. http://dx.doi.org/10.1038/35054664

[7] Mathews, S., Rathinasabapathi, B. and Ma, L.Q. (2011) Uptake and Translocation of Arsenite by Pteris vittala L.: Effects of Glycerol, Antimonite and Silver. Environmental Pollution, 159, 3490-3495. http://dx.doi.org/10.1016/j.envpol.2011.08.027

[8] Yang, C.J., .Zhou, Q.X., Wei, S.H., Hu, Y.H. and Bao, Y.Y. (2011) Chemical Assisted Phytoremediation of Cd-PAHs Contaminated Soils Using Solanum nigrum L. International Journal of Phytoremiation, 13, 818-833. http://dx.doi.org/10.1080/15226514.2010.532179

[9] Küpper, H., Lombi, E., Zhao, F.J. and McGrath, S.P. (2000) Cellular Compartmentation of Cadmium and Zinc in Relation to Other Elements in the Hyperaccumulator Arabidopsis halleri. Planta, 212, 75-84. http://dx.doi.org/10.1007/s004250000366

[10] Morishirta, T. and Boratynski, K. (1992) Accumulation of Cd and Other Metals in Organs of Plants Growing around Metal Smelters in Japan. Soil Science and Plant Nutrition, 38, 781-785. http://dx.doi.org/10.1080/00380768.1992.10416712

[11] Gupta, A.K., Agarwal, H.R. and Dahama, A.K. (1998) Taramira: A Potential Oilseed Crop for the Marginal Lands of Rajasthan, India. In: Bassam, N., Behl, R.K. and Prochnow, B., Eds., Sustainable Agriculture for Food, Energy and Industry, James and James (Science Publishers) Ltd., London, 687-691.

[12] Sastry, E.V.D. (2003) Tarmira (Eruca sativa) and Its Improvement-A Review. Agriculture Review, 24, $235-249$.

[13] Sun, W.C., Pan, Q.Y., Liu, Z.G., Meng, Y.X., Zhang, T., Wang, H.L. and Zeng, X.C. (2004) Genetic Resources of Oilseed Brassica and Related Species in Gansu Province, China. Plant Genet Resources, 2, 167-173. http://dx.doi.org/10.1079/PGR200446

[14] Warwick, S.I., Gukel, R.K., Gomez-Campo, C. and James, T. (2007) Genetic Variation in Eruca vesicaria (L.) Cav. Plant Genetic Resources: Characterization and Utilization, 5, 142-153. http://dx.doi.org/10.1017/S1479262107842675

[15] Shinwari, S., Mumtaz, A.S., Rabbani, M.A., Akaar, F. and Shinwari, Z.K. (2013) Genetic Divergence in Taramira (Eruca sativa L.) Germplasm Based on Quantitative and Qualitative Characters. Pakistan Journal of Botany, 45, 375381.

[16] Huang, B., Liao, S., Cheng, C., Ye, X., Luo, M., Li, Z., Cai, D., Wu, W. and Huang, B. (2014) Variation, Correlation, Regression and Path Analyses in Eruca sativa Mill. African Journal of Agricultural Research, 9, 3744-3750.

[17] Yaniv, Z., Schafferman, D. and Amar, Z. (1998) Tradition, Uses and Biodiversity of Rocket (Eruca sativa, Brassicaceae) in Israel. Economic Botany, 52, 394-400. http://dx.doi.org/10.1007/BF02862069

[18] Sharma, A., Gontia-Mishra, I. and Srivastava, A.K. (2011) Toxicity of Heavy Metals on Germination and Seedling Growth of Salicornia brachiata. Journal of Phytology, 3, 33-36.

[19] Slater, S.M.H., Keller, W.A. and Scoles, G. (2011) Agrobacterium-Mediated Transformation of Eruca sativa. Plant Cell, Tissue and Organ Culture, 106, 253-260. http://dx.doi.org/10.1007/s11240-010-9915-1

[20] Sun, W.C., Guan, C.Y., Meng, Y.X., Liu, Z.G., Zhang, T., Li, X., Yang, S.Z., Ling, L.J., Chen, S.Y., Zeng, X.C. and Wang, H.L. (2005) Intergeneric Crosses between Eruca sativa Mill. and Brassica Species. Acta Agronomica Sinica, 31, 36-42.

[21] Guan, C.Y., Li, F.Q., Li, X., Chen, S.Y., Liu, Z.S., Wang, G.H. and Sun, W.C. (2004) Resistance of Rocket Salad (Eruca sativa Mill.) to Stem Rot (Sclerotinia sclerotiorum). Scientia Agricultura Sinica, 37, 1138-1143.

[22] Su, J., Wu, S., Xu, Z., Qiu, S., Luo, T., Yang, Y., Chen, Q., Xia, Y., Zou, S., Huang, B. L. and Huang, B. (2013) 
Comparison of Salt Tolerance in Brassicas and Some Related Species. American Journal of Plant Sciences, 4, 19111917. http://dx.doi.org/10.4236/ajps.2013.410234

[23] Bashmakov, D.I., Lukatkin, A.S., Revin, V.V., Duchovskis, P., Brazaitytë, A. and Baranauskis, K. (2005) Growth of Maize Seedlings Affected by Different Concentrations of Heavy Metals. Ekologija, 3, 22-27.

[24] Mahmood, T., Islam, K.R. and Muhammad, S. (2007) Toxic Effects of Heavy Metals on Early Growth and Tolerance of Cereal Crops. Pakistan Journal of Botany, 39, 451-462.

[25] Aydinalp, C. and Marinova S. (2009) The Effects of Heavy Metals on Seed Germination and Plant Growth on Alfalfa Plant (Medicago sativa). Bulgarian Journal of Agricultural Science, 15, 347-350.

[26] Hu, J., Deng, Z., Wang, B., Zhi, Y., Pei, B., Zhang, G., Luo, M., Huang, B., Wu, W. and Huang, B. (2015) Influence of Heavy Metals on Seed Germination and Early Seedling Growth in Crambe abyssinica, a Potential Industrial Oil Crop for Phytoremediation. American Journal of Plant Sciences, 6, 150-156. http://dx.doi.org/10.4236/ajps.2015.61017

[27] Taylor, G.J. and Foy, C.D. (1985) Differential Uptake and Toxicity of Ionic and Chelated Copper in Triticum aestivum. Canadian Journal of Botany, 63, 1271-1275.

[28] Wheeler, D.M., Power, I.L. and Edmeades, D.C. (1993) Effect of Various Metal Ions on Growth of Two Wheat Lines Known to Differ in Aluminium Tolerance. Plant and Soil, 155-156, 489-492. http://dx.doi.org/10.1007/BF00025090

[29] Li, W., Khan, M.A., Yamaguchi, S. and Kamiya, Y. (2005) Effects of Heavy Metals on Seed Germination and Early Seedling Growth of Arabidopsis thaliana. Plant Growth Regulation, 46, 45-50. http://dx.doi.org/10.1007/s10725-005-6324-2

[30] Shaikh, I.R., Shaikh, P.R., Shaikh, R.A. and Shaikh, A.A. (2013) Phytotoxic Effects of Heavy Metals (Cr, Cd, Mn and Zn) on Wheat (Triticum aestivum L.) Seed Germination and Seedlings Growth in Black Cotton Soil of Nanded, India. Research Journal of Chemical Sciences, 3, 14-23.

[31] Li, T., Yang, X., Lu, L., Islam, E. and He, Z. (2009) Effects of Zinc and Cadmium Interactions on Root Morphology and Metal Translocation in a Hyperaccumulating Species under Hydroponic Conditions. Journal of Hazardous Materials, 169, 734-741. http://dx.doi.org/10.1016/j.jhazmat.2009.04.004

[32] Keilig, K. and Ludwig-Müller, J. (2009) Effect of Flavonoids on Heavy Metal Tolerance in Arabidopsis thaliana Seedlings. Botanical Studies, 50, 311-318.

[33] Freeman, J.L. and Salt, D.E. (2007) The Metal Tolerance Profile of Thlaspi goesingense Is Mimicked in Arabidopsis thaliana Heterologously Expressing Serine Acetyl-Transferase. BMC Plant Biology, 7, 63. http://dx.doi.org/10.1186/1471-2229-7-63

[34] Al-Qurainy, F. (2010) Application of Inter Simple Sequence Repeat (ISSR Marker) to Detect Genotoxic Effect of Heavy Metals on Eruca sativa (L.). African Journal of Biotechnology, 9, 467-474.

[35] Ozdener, Y. and Aydin, B.K. (2010) The Effect of Zinc on the Growth and Physiological and Biochemical Parameters in Seedlings of Eruca sativa (L.) (Rocket). Acta Physiologiae Plantarum, 32, 469-476. http://dx.doi.org/10.1007/s11738-009-0423-z

[36] Nasr, N. (2013) Germination and Seedling Growth of Maize (Zea mays L.) Seeds in Toxicity of Aluminum and Nickel. Merit Research Journal of Environmental Science and Toxicology, 1, 110-113.

[37] Schaaf, G., Honsbein, A., Meda, A.R., Kirchner, S., Wipf, D. and Von Wiren, N. (2006) AtIREG2 Encodes a Tonoplast Transport Protein Involved in Iron-Dependent Nickel Detoxification in Arabidopsis thaliana Roots. Journal of Biological Chemistry, 281, 25532-25540. http://dx.doi.org/10.1074/jbc.M601062200

[38] Heidari, M. and Sarani, S. (2011) Effects of Lead and Cadmium on Seed Germination, Seedling Growth and Antioxidant Enzymes Activities of Mustard (Sinapis arvensis L.). ARPN Journal of Agricultural and Biological Science, 6, 4447.

[39] de Souza Costa, E.T., Guilherme, L.R.G., de Melo, É.E.C., Ribeiro, B.T., dos Santos, B., Inácio, E., da Costa Severiano, E., Faquin, V. and Hale, B.A. (2012) Assessing the Tolerance of Castor Bean to Cd and Pb for Phytoremediation Purposes. Biological Trace Element Research, 145, 93-100. http://dx.doi.org/10.1007/s12011-011-9164-0

[40] Zhu, Y.L., Pilon-Smits, E.A.H., Jouanin, L. and Terry, N. (1999) Overexpression of Glutathione Synthetase in Indian Mustard Enhances Cadmium Accumulation and Tolerance. Plant Physiology, 119, 73-79. http://dx.doi.org/10.1104/pp.119.1.73

[41] Zhao, F.J., Jiang, R.F., Dunham, S.J. and McGrath, S.P. (2006) Cadmium Uptake, Translocation and Tolerance in the Hyperaccumulator Arabidopsis halleri. New Phytologist, 172, 646-654. http://dx.doi.org/10.1111/j.1469-8137.2006.01867.x

[42] Saleh, A.A.H. (2001) Effect of $\mathrm{Cd}$ and $\mathrm{Pb}$ on Growth, Certain Antioxidant Enzymes Activity, Protein Profile and Accumulation of $\mathrm{Cd}, \mathrm{Pb}$ and $\mathrm{Fe}$ in Raphanus sativus and Eruca sativa Seedlings. Egyptian Journal of Biology, 3, 131139. 
[43] Li, D., Zhang, X., Li, G., Deng, D. and Zou, H. (2008) Effects of Heavy Metal Ions on Germination and Physiological Activity of Festuca arundinacea Seed. Pratacultural Science, 25, 98-102.

[44] Cargnelutti, D., Tabaldi, L.A., Spanevello, R.M., de Oliveira Jucoski, G., Battisti, V., Redin, M., Linares, C.E.B., Dressler, V.L., de Moraes Flores, E.M., Nicoloso, F.T., Morsch, V.M. and Schetinger, M.R.C. (2006) Mercury Toxicity Induces Oxidative Stress in Growing Cucumber Seedlings. Chemosphere, 65, 999-1006. http://dx.doi.org/10.1016/j.chemosphere.2006.03.037

[45] Meng, D.K., Chen, J. and Yang, Z.M. (2011) Enhancement of Tolerance of Indian Mustard (Brassica juncea) to Mercury by Carbon Monoxide. Journal of Hazardous Materials, 186, 1823-1829. http://dx.doi.org/10.1016/j.jhazmat.2010.12.062

[46] Shiyab, S., Chen, J., Han, F.X., Monts, D.L., Matta, F.B., Gu, M. and Su, Y. (2009) Phytotoxicity of Mercury in Indian Mustard (Brassica juncea L.). Ecotoxicology and Environment Safety, 72, 619-625. http://dx.doi.org/10.1016/j.ecoenv.2008.06.002

[47] Shen, Q., Jiang, M., Li, H., Che, L.L. and Yang, Z.M. (2011) Expression of a Brassica napus Heme Oxygenase Confers Plant Tolerance to Mercury Toxicity. Plant Cell Environment, 34, 752-763. http://dx.doi.org/10.1111/j.1365-3040.2011.02279.x

[48] Gang, A., Vyas, H. and Vyas, A. (2013) A Study of Heavy Metal Toxicity on Germination and Seedling Growth of Soybean. Science Secure Journal of Biotechnology, 2, 5-9.

[49] Zulfiqar, A., Paulose, B., Chhikara, S. and Dhankher, O.P. (2011) Identifying Genes and Gene Networks Involved in Chromium Metabolism and Detoxification in Crambe abyssinica. Environmental Pollution, 159, 3123-3128. http://dx.doi.org/10.1016/j.envpol.2011.06.027 